\title{
On the Issues of the Structural Methodology of Sustainable Development
}

\author{
Sergey Kovalevsky ${ }^{1}$, Albert Falaleev ${ }^{2}$, Eyvaz Gasanov ${ }^{3}$, Maria Konovalova ${ }^{4}$, and Nadezhda \\ Reimer $^{5}$ \\ ${ }^{1}$ T.F. Gorbachev Kuzbass State Technical University, 650000 Kemerovo, 28 Vesennya st., \\ Kemerovo, Russia \\ ${ }^{2}$ Siberian Federal University, 660075 Lida Prushinskaya St. 2, Krasnoyarsk, Russia \\ ${ }^{3}$ Khabarovsk State University of Economy and Law, Economics Department of International \\ Economic Relations Faculty, 680042134 Tikhookeanskaya st., Khabarovsk, Russia \\ ${ }^{4}$ Samara State University of Economics, 443090141 Soviet Army st., Samara, Russia \\ ${ }^{5}$ Kuzbass State Technical University, Mezhdurechensk branch, 652881, Stroitelei Avenue, 36, \\ Mezhdurechensk, Russia
}

\begin{abstract}
The whole world, including Russia, is on the verge of a third, after the agrarian and industrial, the digital technological revolution, no less, and perhaps more fundamental, than the two previous ones. A sustainable development strategy cannot be created on the basis of traditional universal human notions and values, stereotypes of thinking. It requires the development of new scientific and ideological approaches that correspond not only to modern realities, but also to the expected development prospects in the 3rd millennium. The transition to sustainable development involves the gradual restoration of natural ecosystems to a level that ensures the sustainability of the environment, and in which there is a real possibility for future generations of people to live up to their vital needs and interests. The formulation of a new development strategy means a structural changes during gradual integration into a single self-organizing system of economic, environmental and social spheres of activity. In this sense, sustainable development implies, at a minimum, structural efficiency and compatibility of the biosphere and the new digital world, social justice with a general decrease in anthropogenic pressure on the biosphere. However, the transition to sustainable development is the only alternative to the development of mankind, since the economics of technologically advanced countries are already forming the foundations of new structural changes that radically change the place of nature-intensive industries in meeting human needs.
\end{abstract}

\section{Introduction}

The concept of sustainable development should be defined through two main signs of such progress - anthropocentric and biospherocentric. The anthropocentric attribute in a broad sense is understood as the survival of mankind (country) and the ability (possibility) of its further unceasing (sustainable), continuously long development, so that our descendants have not less opportunities, compared to the present generation, to meet their needs in natural conditions and environmental conditions (the principle of equality of opportunities for 
generations to meet their needs). The biospherocentric (in general - ecological) feature of the concept of sustainable development is associated with the preservation of the biosphere as the natural basis of all life on Earth, a necessary condition for its stability and natural evolution, so that the further development of mankind does not occur in an ecophobic form.

In the modern economy, biocentrism is formed in the process of structural changes that increase the share of non-material production, the transition to recycling of mineral raw materials, a fundamentally new urbanization. As a result, economic incentives for investors are transformed from maximizing the market value of produced goods to environmental safety and the prestige of cleaner production.

\section{Materials and Methods}

The concept of sustainable development has become a logical transition way from the greening of scientific knowledge and socio-economic development, which began rapidly in the 1970s. The issues of limited natural resources, as well as pollution of the environment, became one of the most important problems of life, economic and any human activity, were discussed in a few research papers [1-3]. The response to this concern was the creation of international non-governmental scientific organizations studying global processes on Earth, such as the International Federation of Advanced Research Institutes, the Rome Club, the International Institute for System Analysis, and the All-Union Institute for System Studies in the USSR [4-5].

In the 1980s, the researchers began to discuss eco-development, development without destruction, the need for sustainable development of ecosystems. The World Conservation Strategy (WCS), adopted in 1980, was the first in an international document to mention sustainable development [6]. The second edition of the WCS was named "Caring for the Planet Earth - Sustainable Living Strategy" and was published in October 1991 [7]. It emphasizes that development should be based on the conservation of living nature, the protection of the structure, functions and diversity of Earth's natural systems on which biological species depend. In the 1980s, the United Nations Environment Program (UNEP) called for a transition to "development without destruction". In 1980, for the first time, the concept of sustainable development was widely publicized in the World Conservation Strategy, developed at the initiative of UNEP, the International Union for Conservation of Nature (IUCN) and the World Wide Fund for Nature. In 1987, in the "Our Common Future" report, the International Commission on Environment and Development focused on the need for "sustainable development", in which "meeting the needs of the present tense does not undermine the ability of future generations to meet their own needs [8]. This formulation of the concept of "sustainable development" is now widely used as a basic in many countries.

In June 1992, the UN Conference on Environment and Development (UNCED) was held in Rio de Janeiro, at which a historic decision was taken to change the course of development of the entire world community [9]. Such an unprecedented decision of the heads of government and leaders of the 179 countries gathered at UNCED was due to the rapidly deteriorating global environmental situation and the predicted global catastrophe that may break out in the 21st century and lead to the death of all life on the planet. Among the environmental problems, according to the Global Environment Outlook 2000 (GEO-2000) [10] and the report of the United Nations Environment Program (UNEP) [11], that will be the main ones in the 21 st century, there are climate change due to greenhouse gas emissions, freshwater deficit and its pollution, deforestation and desertification, reduction of biodiversity, population growth (and its movement), the need for waste disposal, air pollution, degradation of soils and ecosystems, chemical pollution, ozone depletion layer, urbanization, depletion of natural resources, violation of biogeochemical cycles, the spread of diseases (including the emergence of new ones), etc. Almost each of these environmental 
problems can, if the spontaneous development of civilization continues, lead to the death of mankind and the biosphere. UNCED demonstrated an awareness of the destructiveness of the traditional development path, which was described as unsustainable development, fraught with crises, catastrophes.

The term "sustainable development" was widely adopted after the publication of a report prepared for the UN in 1987 by the International Commission on Environment and Development, specially created in 1983 [12]. In the Russian edition of this report, the English term sustainable development is translated as "sustainable progress", although the word sustainable has other meanings: "supported, self-sustaining", "long-term, continuous", "reinforced", "protected".

In the 1980s, the problems of connection of ecology and development were particularly actively discussed in the papers of scientists from the Worldwatch research institute in the United States, and in particular its director L.R. Brown since the mid-1970s [13]. UNEP has widely used the concept of "development without destruction", and the concept of "ecodevelopment" has become widespread, meaning environmentally acceptable development, i.e. development that has the least negative impact on the environment.

R. Costanza and K. Folke distinguish three hierarchically interrelated problems, the solution of which is related to sustainable development [14]. They can be assumed in the following way:

- sustainable scale of the economy, which would correspond to its ecological life support system;

- equitable distribution of resources and opportunities not only within the current generation of people, but also between current and future generations, as well as between humans and other biological species;

- efficient allocation of resources over time, which would adequately take into account the natural capital.

Most of the representatives of traditional economics believed that the distributional problem should be solved by political rather than economic methods. The scale problem was not even considered as significant, as the possibility of endless replacement of resources and technological changes was recognized. It is important that the problem of scale and distributional problem cannot be solved within the framework of the market mechanism even under the condition of a perfect "market in the sense of taking into account all external costs. Rather, the solution to these problems should be found outside the market, but the market can be used as an effective tool for implementing these solutions in life.

\section{Results and Discussion}

The traditional paradigm largely ignores the problem of scale and distributional problem as being "outside the scope of" economics. Economics is regarded as limited to solving technical issues arising from the efficient allocation of resources. But if economic science is defined more broadly, namely, "the science of economic management" (the Greek word "economy" carries this meaning) [15], then it should address all the problems arising during such management, including the problem of the structure of the economy and the distributional problem, even if the latter do not fit into the framework of mathematical models and traditional prescriptions used in solving the problem of efficient allocation of resources.

Theory and practice have shown that the environmental component is an integral part of economic structure's development. The activities of the International Commission on Environment and Development and its final report, "Our Common Future" [8], were based on a new triune concept of sustainable (environmental, social and economic) development. The UN World Summit on Sustainable Development (intergovernmental, non-governmental and scientific forums) in 2002 reaffirmed the commitment of the entire world community to 
the ideas of sustainable development for the long-term satisfaction of basic human needs while maintaining the life support systems of planet Earth. The concept of sustainable development has much in common with the concept of the noosphere put forward by Academician V.I. Vernadsky still in the middle of the XX century [16].

Consideration of social, economic and environmental parameters in a single complex has become universally recognized. Naturally, the criteria or indicators of sustainable development should reflect these three most important components of civilization. On the other hand, development can be viewed as a change of states, each of which is characterized by a certain stability and ability to change. It is in these three planes that the formation of a system of criteria for sustainable development is expanding.

The term "sustainable development" itself would be better translated as "structurally balanced development". Since not the words themselves are important, but the content that fills the concepts corresponding to them, the already established terminology can be used, it must be borne in mind that "sustainability" in the case of "sustainable development" has, of course, procedural character and is the result continuous balancing of multidirectional trends.

Therefore, the structural concept of sustainable development is preferred because it is about changing the competitive type of behavior to the consensual one. This means the formation of its own structure for the system of sustainable development, formed by the following components:

1. The economic component. The economic approach to the concept of sustainable development is based on the theory of the maximum flow of Hicks-Lindahl's total income [17], which can be produced under the condition, at least, of preserving the total capital, with the help of which this income is generated. This concept implies the optimal use of limited resources and the use of environmentally friendly energy and material-saving technologies, including the extraction and processing of raw materials, the creation of environmentally acceptable products, minimization, recycling and disposal of waste. However, when deciding what capital should be conserved (for example, physical, natural or human capital) and to what extent various types of capital are interchangeable, some problems arise in correct interpretation and counting (as well as for valuation of these assets, especially environmental resources). To solve the counting problems, there are two types of sustainability were underlined: the weak one, when it comes to natural and produced capital that is undiminished over time, and strong one, when natural capital must not decrease (and part of the profits from the sale of non-renewable resources should be used to increase the value of renewable natural capital).

2. The social component. The social part of sustainability is focused on people and is aimed at preserving the stability of social and cultural systems, including reducing the number of destructive conflicts between people. An important aspect of this approach is the fair sharing of benefits. It is also desirable to preserve cultural capital and diversity on a global scale, as well as more fully utilize the practice of sustainable development found in non-dominant cultures. In order to achieve sustainable development, modern society will have to create a more effective decision-making system, taking into account historical experience and encouraging pluralism. It is important to achieve not only intra- but also intergenerational fairness. Within the framework of the concept of human development, human is not an object, but a subject of development. Based on the expansion of options for choosing a person as the main value, the concept of sustainable development implies that a person should participate in the processes that form the sphere of his life activity, facilitate the adoption and implementation of decisions, and control their implementation.

3. Ecological component. From an environmental point of view, sustainable development should ensure the integrity of biological and physical natural systems. Of particular importance is the viability of ecosystems on which the global stability of the entire biosphere depends. Moreover, the concept of "natural" systems and habitats can be understood broadly, 
including in them a human-created environment, such as, for example, cities. The focus is on preserving the ability to heal itself and dynamically adapt such systems to change, rather than preserving them in a certain "ideal" static state. The degradation of natural resources, environmental pollution and the loss of biological diversity reduce the ability of ecological systems to heal itself.

Harmonization of these different points of view and their translation into the language of specific activities that are the means to achieve sustainable development is a task of great complexity, since all three elements of sustainable development should be considered balanced. The mechanisms of interaction of these three concepts are also important. The economic and social elements, interacting with each other, give rise to such new tasks as achieving equity within one generation (for example, with respect to income distribution) and providing targeted assistance to the poor. The mechanism of interaction of economic and environmental elements has given rise to new ideas regarding the valuation and internalization (accounting in the economic reporting of enterprises) of external environmental impacts. Finally, the connection of social and environmental elements has aroused interest in issues such as intergenerational equality, including respect for the rights of future generations, and public participation in the decision-making process.

\section{Conclusions}

The transition to sustainable development of the economy as a whole is possible only if the sustainable development of all its structural elements is ensured. This presupposes the formation of an effective spatial structure of the country's economy. Respecting the balance of interests of all economic actors predetermines the need to develop and implement programs for the transition to sustainable development by changing structural proportions of economy, as well as by further integration of sectoral development programs into national sustainable development policies. The problems being solved in each industry should correspond to macroeconomic problems, but it is necessary to take into account local peculiarities.

The concept of sustainable development is characterized by the selection of the main "counter-trends", the balancing of which is capable of ensuring the survival of mankind at a qualitatively acceptable level. Discussing the relevant requirements allows us to formulate the structural principles of sustainable development: the balance between nature and society (directly for the economy); balance within society at the present stage of its development (between individual countries and their regions); balance between the current and future state of humanity as a certain "target function" of development (the requirement to preserve the vital resources of nature for future generations).

\section{References}

1. S. Zhironkin, D. Khloptsov, N. Skrylnikova, I. Petinenko, O. Zhironkina, E3S Web Conf., 41, 04010 (2018)

2. S. Zhironkin, S. Demchenko, G. Kayachev, M. Ryzhkova, O. Zhironkina, E3S Web Conf., 41, 04011 (2018)

3. S. Zhironkin, M. Gasanov, G. Barysheva, E. Gasanov, O. Zhironkina, G. Kayachev, E3S Web Conf., 21, 04002 (2017)

4. E.A. Gasanov, T.S. Boyko, N.S. Frolova, Economics and Innovation Management, 3, (2018) 4-8 C.. DOI: 10.26730/2587-5574-2018-3-4-8 
5. S. Zhironkin, S. Demchenko, G. Kayachev, M. Ryzhkova, O. Zhironkina, E3S Web Conf., 41, 04011 (2018)

6. P.H. Selman, Environmentalist, 5:4, 263-268 (1985)

7. Caring for the Earth: A Strategy for Sustainable Living. URL: https://gcmd.nasa.gov/records/GCMD_IUCN_CARING.html

8. Report of the World Commission on Environment and Development: Our Common Future. URL: http://www.un-documents.net/our-common-future

9. United Nations Conference on Environment and Development. "Agenda 21: Earth Summit, 1992" (UN, Washington, 1992)

10. Global Environment Outlook 2000 (GEO-2000) (UN, Washington, 1999)

11. The United Nations Environment Programme (UNEP) (The agency of the United Nations, Washington, 1972)

12. I.G. McChesney The Brundtland Report and sustainable development in New Zealand (Lincoln University and University of Canterbury, Canterbury, 1991)

13. L.R. Brown, B. Halweil, World Watch, 12:5, 9-20 (1999)

14. R. Costanza, et. al., Nature, 387, 253-260 (1997)

15. S.A. Zhironkin, K.A. Kolotov, A.E. Genin, F.V. Agafonov, S.A. Kovalevsky, IOP Conf. Ser.: Earth Environ. Sci., 50:1, 012011 (2017)

16. M. Cehlár, J. Janočko, Z. Šimková, T. Pavlik, M. Tyulenev, S. Zhironkin, M. Gasanov, Resources, 8:1, 21 (2019)

17. L.S. Sagdeeva, L.N. Starikova, Economics and Innovation Management, 3, 51-59 (2018) DOI:10.26730/2587-5574-2018-3-51-59 